\title{
Lymphoma of the nasolacrimal drainage system
}

\author{
Лимфома на слъзния апарат
}

\author{
N. Sapundzhiev'1, D. Marev' I. Krasnaliev², M. Alamo \\ ${ }^{1}$ Department of Neurosurgery, Otorhinolaryngology and Ophthalmology, \\ St. Marina University hospital - Varna; \\ 2Department of General and clinical pathology, St. Marina University hospital - Varna; \\ ${ }^{3}$ Department of Radiology, St. Marina University hospital - Varna.
}

\author{
Н. Сапунджиев ${ }^{1}$, Д. Марев ${ }^{1}$, И. Красналиев², М. Alamo³ \\ ${ }^{1}$ Катедра по неврохирургия, УНГ-болести и офталмология, МБАЛ "Св. Марина" - Варна \\ ГКатедра по обща и клинична патология, МБАЛ "Св. Марина" - Варна \\ ЗКатедра по радиология, МБАЛ "Св. Марина" - Варна
}

\begin{abstract}
Introdustion: Primary lymphoma of the lacrimal drainage system (LDS) presents an extremely rare condition.

Case report: We represent a clinical case of a 70-year old female patient, which preseneted at the Department of oto-rhinolaryngology with complains of a mass over right median eye angle with local pain and epiphora since approximately 3 months. Head CT scan revealed solid tumoral mass. Surgical resection was performed. The specimen was stained with H\&E and an immunohistochemical panel with antibodies directed against CD3 and CD20 was applied. B-cell non-Hodgkin's lymphoma (NHL) was diagnosed. The patient was staged as stage IV HNL.

Conclusion: Primary involvement of LDS by NHL is extremely rare. The most cases described in the literature are of the B-cell type, the T-cell type being extreme rareness. As only of patients with LDS involvement the incidence of NHL is estimated at $1 / 2000$
\end{abstract}

\section{Резюме}

Въведение: Първичното засягане на слъзните пътища от лимфоми представлява много рядко състояние.

Клиничен случай: Представяме клиничен случай на 70 годишна пациентка, която се обърна за лечение към клиниката по УНГ болести с оплаквания от поява на туморна маса в медиалния очен ъгъл, локална болка и епифора. Оплакванията бяха с давност около 3 мессца. Проведсната компютърна томография на областта показа солидна туморна маса без костна деструкция. Проведена бе хирургична резекция на формацията. Материальт бе обработен стандартно хистологично с $\mathrm{X} \& \mathrm{E}$ и имунохистохимично за CD3 и CD20. Диагнозата бе В-клетъчен non-Hodgkin's lymphoma (NHL). Допълнителното

\section{Introduction}

Lacrimal drainage system (LDS) is a location, which could be involved in lymphoproliferative disorders. However LDS lymphoma as primary manifestation is extremely rare $[3,5]$. On the other hand the differentiation between primary, secondary LDS lymphoma (systematic spread) and LDS lymphoma as first clinical manifestation of this condition is difficult and dependent on staging procedure used.

\section{Case report}

A 70 -year old female presented at the Department of oto-rhino-laryngology Head and Neck surgery at the St. Marina University hospital in Varna with complains of a palpable mass over the right median eye angle with local pain and epiphora since approximately 3 months. The mass was approximately $2,5 \mathrm{~cm}$ with no signs of fluctuation or inflammatory changes in the overlying skin. Head CT scan revealed solid tumoral mass without osteolytic changes and no involvement of the eyeball and orbital fat pad (Fig. 1) 
стадиране определи пациентката като IV стадий HNL.

Заключение: Първичното засягане на слъзните пътища от лимфоми (NHL) представлява рядко състояние. Болшинството от описаните в литературата случаи са на В-клетъчни лимфоми, докато Т-клетъчните са казуистика. Лимфомите са около 1/2000 от всички случаи на патология на слъзните пътища.

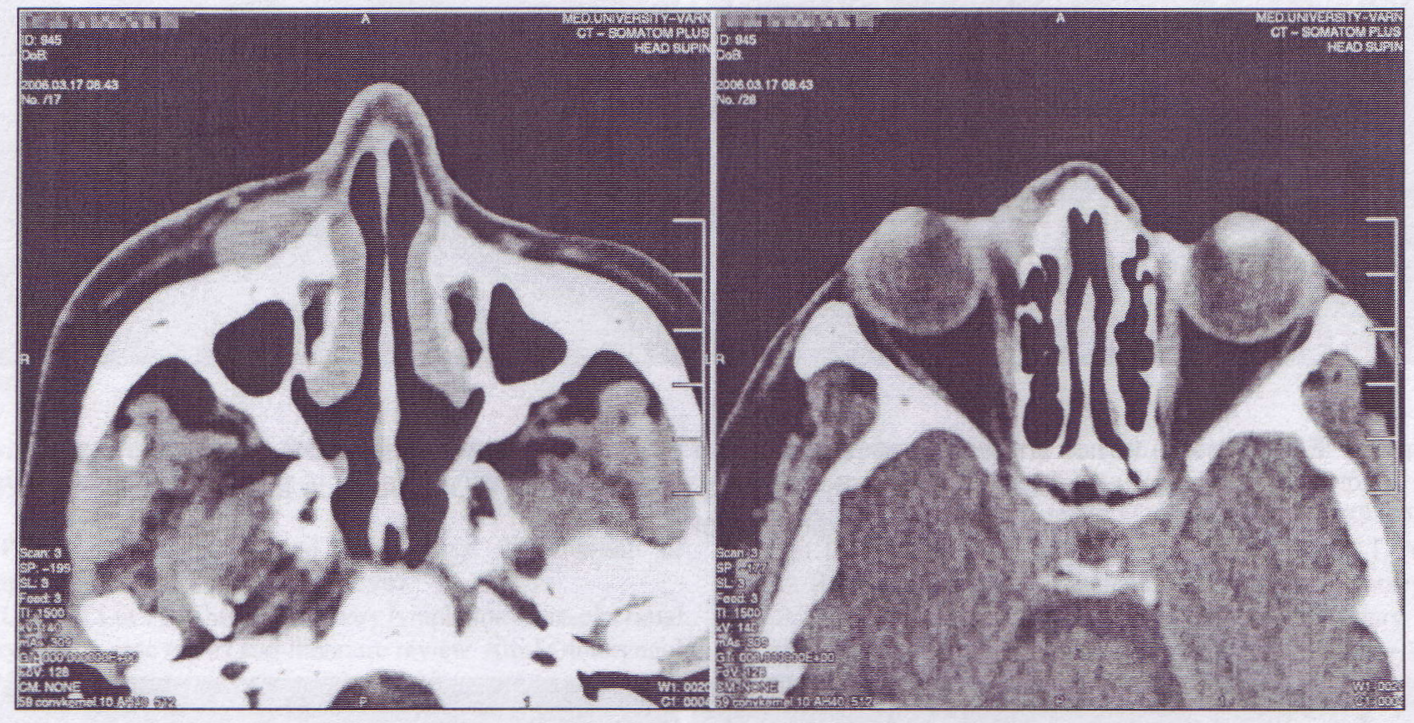

Fig. 1: Axial CT scans of the sinuorbital complex show a well delineated tumor, which appears solid and not cystic and without osteolytic changes of the surrounding bony structures.

No enlarged regional lymph nodes were observed. The patient was subjected to surgery, aiming of acquiring sample for histological clarification and tumor removal (Fig. 2).

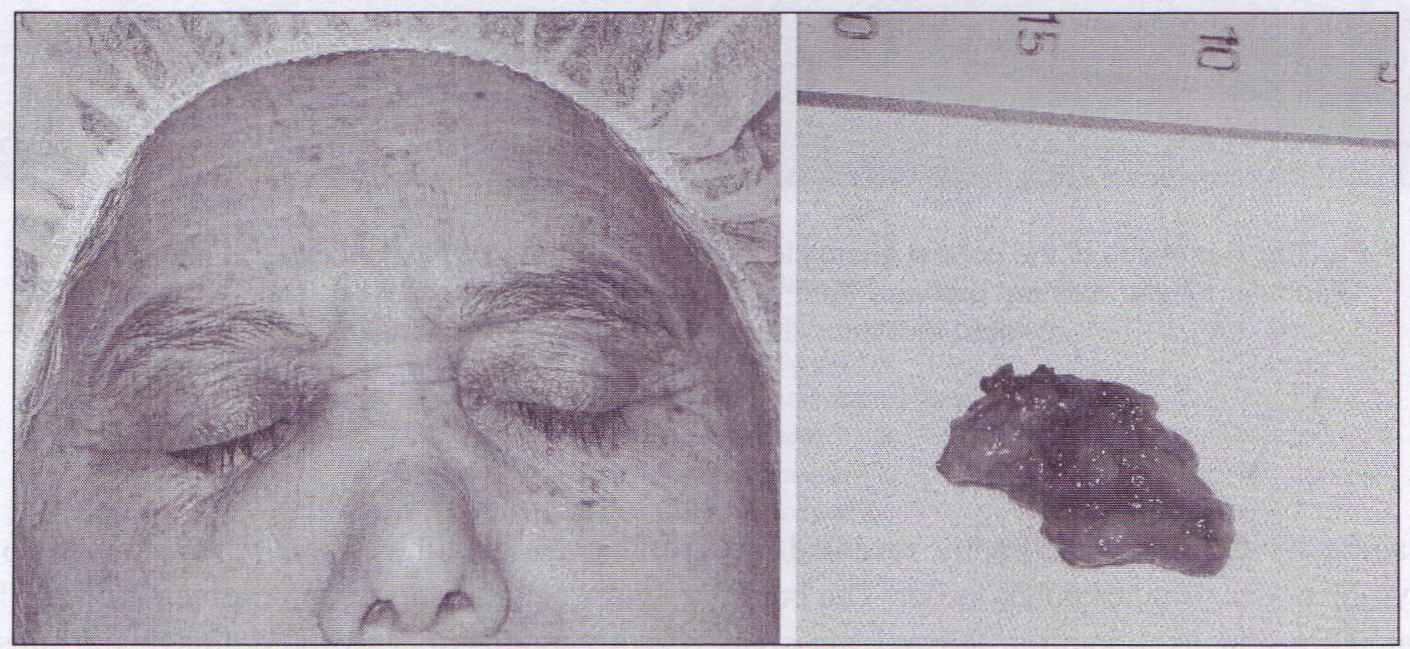

Fig. 2: Bulky mass in the right medial eye angle - no signs of acute inflammation. Macroscopic aspect of the resected specimen.

The postoperative course was uneventful, the patient recovered quickly and was discharged on the 4-th postoperative day. The surgical specimen obtained was stained with hemalaun and eosin and an immunohistochemical panel with antibodies directed against CD3 and CD20 surface antigens was applied. The tumoral mass was characterized by pronounced infiltration with lymphocytes. The expression of CD20 defined it as B-cell non-Hodgkin's lymphoma (NHL). 

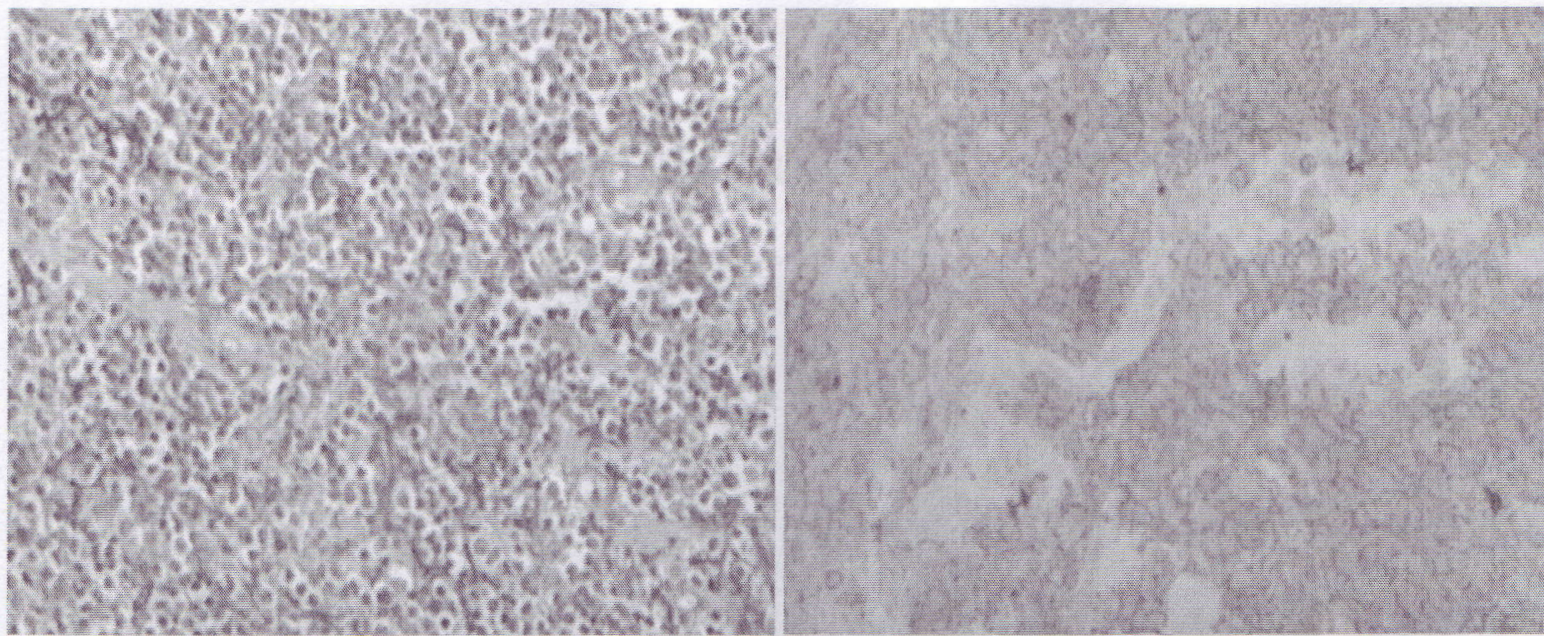

Fig. 3a: The tumor shows massive infiltration by lymphocytes (hemalaun \& eosin staining); Immunohistochemistry study showed expression of CD20 surface antigen indicative of B-cell NHL.
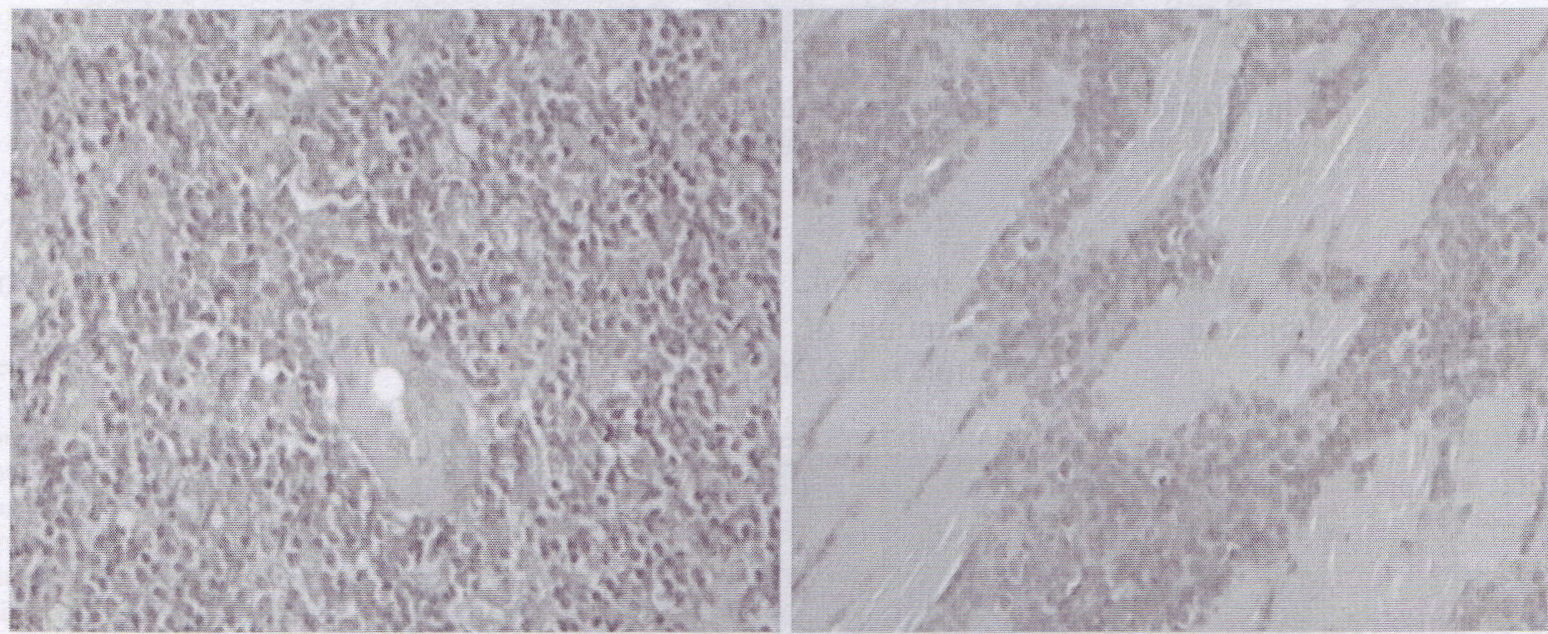

Fig. 3b: Remnants of the normal anatomic structures infiltrated by lymphocytes in the specimen: Glandular tubular element probably from Wolfring's or Krause's accessory lacrimal glands (left); striated muscular fibers from orbicularis oculi (right).

Further staging by $\mathrm{CT}$ and sonography revealed no enlarged lymph nodes or other bulky tumor. The bone marrow puncture and examination showed massive infiltration with NHL cells. The presence of this massive bone marrow infiltration corresponded to stage IV HNL. Treatment with the CHOP protocol was started and oncologic control was achieved in this patient.

\section{Discussion}

Undoubtfully the most common pathologic condition in this area is the acute or chronic dacryocystitis [4].
The clinical findings are characteristic of acute but more often chronic suppurative process. The substrate corresponds to impaired drainage and subsequent formation of a cyst. This can only very uncommonly be due to haematoma etc. [2]. However the dacryocystitis could hide an underlying lymphoma [5] or other malignancies, which rises the need for obligatory histologic examination of speciments obtained from "routine" dacryocystorhinostomies [4].

Solid tumors are rare with epithelial ones accounting for about $90 \%$ of all cases [3]. The histological types include pleomorphic adenoma, adenoid cystic carci- 
noma, adenocarcinoma myoepithelioma etc [1]. Lymphomas are not uncommon and constitute about 10\% of all tumors in the ocular region [5]. Predominantly these represent secondary involvement of the LDS by the NHL as a result of the systemic spread. Primary LDS lymphomas are extremely rare (about 30 cases publicated worldwide so far) $[3,5]$. In the huge number of cases these are B-cell lymphomas with only 1 case of T-cell lymphoma reported [5]. Primary clinical manifestation of stage IV NHL in the LDS has never been reported.

\section{Bibliography}

1. Bolzoni A, Pianta L, Farina D, Nicolai P. Benign myoepithelioma of the lacrimal gland: report of a case Eur Arch Otorhinolaryngol 2005; 262: 186-188

2. Devesa PM. Spontaneous orbital haematoma The Journal of Laryngology and Otology 2002; 116: 960-961

3. Gao HW, Lee HS, Lin YS, Sheu LF. Primary lymphoma of nasolacrimal drainage system: a case report and literature review. Am J Otolaryngol $2005 ; 26: 356-359$

\section{Conclusion}

Primary involvement of LDS by NHL is extremely rare. The most cases described in the literature are of the B-cell type, the T-cell type being extreme rareness. As only of patients with LDS involvement the incidence of NHL is estimated at $1 / 2000$. Besides NHL other malignancies and other systemic disorders may involve the LDS. This advocates to routinely perform histological examination of any surgical specimen resected in the course of surgery for dacryocystitis.

4. Merkonidis C, Brewis C, Yung M, Nussbaumer M. Is routine biopsy of the lacrimal sac wall indicated at dacryocystorhinostomy? A prospective study and literature review Br J Ophthalmol 2005; 89: 1589-1591

5. Sjö LD, Ralfkiaer E, Juhl BR, Prause JU, Kivelä T, Auw-Haedrich C, Bacin F, Carrera M, Coupland SE, Delbosc B, Ducrey N, Kantelip B, Kemeny JL, Meyer P, Sjö NC, Heegaard S. Primary lymphoma of the lacrimal sac: an EORTC ophthalmic oncology task force study Br J Ophthalmol 2006; 90: 1004-1009

Corresponding author:

Dr. N. Sapundzhiev MD,

Department of Otorhinolaryngology,

St. Marina University hospital

1, Christo Smirnenski blvd.

Varna - 9010, Bulgaria

e-mail:n.sapundzhiev@gmail.com

\section{Адрес за кореспонденция:}

д-р Н. Сапунджиев дм,

Катедра по неврохирургия, УНГ-болести и офталмология

МБАЛ "Св. Марина"

бул. "Христо Смирненски" I,

Варна-9010, България

e-mail:n.sapundzhiev@gmail.com

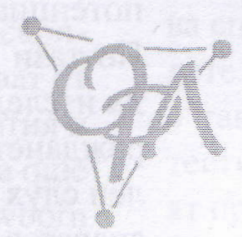

